Article

\title{
Top Management, Green Innovations, and the Mediating Effect of Customer Cooperation in Green Supply Chains
}

\author{
Umar Burki ${ }^{1} *$, Pervin Ersoy ${ }^{2}$ (D) and Usama Najam ${ }^{3}$ (D) \\ 1 School of Business, University of South-Eastern Norway, 3603 Kongsberg, Norway \\ 2 Department of International Logistics Management, Yasar University, 35100 Izmir, Turkey; \\ pervin.ersoy@yasar.edu.tr \\ 3 Management Sciences, Air University (Multan Campus), Multan 60000, Pakistan; usama@aumc.edu.pk \\ * Correspondence: Umar.Burki@usn.no; Tel.: +47-310-093-35
}

Received: 10 January 2019; Accepted: 12 February 2019; Published: 16 February 2019

\begin{abstract}
This study examines the mediating role of customer cooperation in green supply chain relationships. Employing 181 manufacturer-customer relationships, we test the mediating effect of customer cooperation on the process and managerial innovations. As proposed, customer cooperation positively mediates the relationship between top management commitment and process innovation. However, customer cooperation fails to mediate the relationship between top management commitment and managerial innovation. The findings suggest that the magnitude of customer cooperation increases the adoption of green innovations between supply chain partners to mitigate the negative impact on the environment. Furthermore, customer cooperation enforces a sense of mutuality between supply chain partners to diminish the impact of carbon footprint.
\end{abstract}

Keywords: customer cooperation; green innovations; top management commitment; green supply chains

\section{Introduction}

Reducing carbon footprint is now an integral part of supply chains. Businesses realize that when supply chains become greener, they provide them with win-win outcomes such as safeguarding the environment, improving corporate profitability, and opening new market opportunities. For such reasons, business firms adopt and implement green innovations to become greener. Green innovations are a subcategory of sustainable efforts, which firms pursue to address the ecological, social, and economic performance [1]. Current literature [2,3] supports that theory that businesses achieve competitive advantages when they adopt sustainability-driven practices and green innovations. In other words, green innovations (GIs) provide supply chain partners better control and visibility in meeting sustainability (green) objectives.

A green supply chain focuses on minimizing the environmental damage by working closely with supply chain partners that are entirely willing to practice green business practices [4,5]. In this study, we apply green or sustainable supply chains as synonymous, and green supply chain research [4] use them as interchangeable concepts. References [6,7] show that when business firms adopt green innovations and practices, it results in economic profitability, better resource utilization and a reduction in environmental degradation costs. That is why international business firms such as IBM and Xerox encourage their suppliers to improve environmental management systems and bring them by ISO 1400/14001 certifications. Likewise, automobile manufacturers Ford, General Motors and Toyota help their suppliers to fulfill the required environmental certifications to reduce ecological damage [8]. 
In green supply chains, customer cooperation is critical because it helps in developing a reliable sustainable compliance system [5]. Customer cooperation (CC) refers to the extent an exchange partner is willing to work and achieve sustainable outcomes [9]. When exchange partners cooperate, trust develops and increases innovations in a relationship [10]. Adoption of green practices by one of the partners enforces other partners to follow suit [11]. Such support towards sustainable practices between supply chain partners results in providing better levels of sustainable advantages [12,13]. Similarly, developing close cooperation with supply chain customers should strengthen green innovations in supply chains.

Close customer cooperation motivates supply chain partners to adopt and implement green innovations and practices. As a result, this approach would help in diminishing the adverse effect of supply chain activities on the environment. Objectively, green supply chains embrace and implement green innovations that provide superior value to their customers. For instance, green products and green business opportunities. In supply chains, better customer cooperation offers a win-win opportunity for meeting customer demands and improving sustainability efficacy. Adopting green innovations help businesses in maintaining sustainable competitiveness $[14,15]$. In supply chains, sustainable competitiveness act as a competitive tool that provides the needed reputation required by customers and consumers [16]. Hence, it is crucial to examine the role of customer cooperation in enhancing green innovations in green supply chain relationships.

Literature classifies green innovations as product innovations, process innovations, green technologies, managerial functions and manufacturing processes $[17,18]$. In this study, we employ green managerial innovation (GMI) and green process innovation (GPI). Green managerial innovation refers to measures undertaken by a firm to redesign and refine current administrative and services operations to achieve internal environmental efficiency [19]. Green managerial innovation implies undertaking various managerial measures to improve environmental awareness and environmental performance, which reduces the negative impact on the environment [20]. Furthermore, green managerial innovations underscore a radical change in a firm's managerial attitude toward environmental protection. Hence, green managerial innovation accentuates the necessary administrative modifications a firm must undertake to diminish the negative environmental impact.

Green process innovation refers to the improvements made in the existing manufacturing processes and adding new modifications to minimize the harmful effect of hazardous pollution on the environment [18]. In other words, green process innovations focus on specific improvements made in manufacturing operations to optimize resource usage. Implementing new procedures, adopting new innovative technologies to save energy, and reducing pollution during manufacturing are integral elements of green innovations [21]. For instance, using biodegradable materials in manufacturing processes.

Business firm's top management commitment towards sustainability and close cooperation with supply chain partners is vital in developing as well as strengthening green supply chains [19]. This study describes top management commitment (TMC) as the concrete support provided by a firm's top management towards sustainable operations and practices [22]. When a firm's senior management supports and implements sustainable practices with supply chains partners, it provides a supply chain the strategic strength to achieve triple bottom line (TBL) objectives [6]. Adopting and implementing sustainable practices in supply chain operations remain a challenging task. Many studies $[7,9,17,22]$ outline the role of top management commitment, green innovations and customer cooperation in green supply chains. However, there is a limited effort to examine the effect of customer cooperation on the top management-green innovation relationships.

Recent literature [6] identifies the role of top management commitment and green innovations in achieving sustainability goals in supply chains. Nevertheless, there is a lack of evidence regarding the mediating effect of customer cooperation on the relationship between top management and green innovations in green supply chains. The goal of this research is two-dimensional. First, this research identifies the strategic role of customer cooperation as a reinforcing antecedent in 
achieving sustainability objectives in supply chains. Second, the study highlights the combine roles of internal and external environment processes in pursuing challenging sustainability goals in supply chains. Overall, our research shows that an alignment of internal and external environmental processes helps achieves greener supply chains.

In the next section, we outline the conceptual model and hypotheses. Section 3 provides the data collection procedures, measurement constructs and data validity. Section 4 outlines the results. Finally, Section 5 includes discussion and conclusion.

\section{Conceptual Model and Hypotheses}

Internally, green supply chains demand dedicated green innovations focused on changing organizational structures and business operations. Externally, one of the essential requirements for green supply chains is to have a close collaborative relationship with collaborating customers. Top management commitment is one of the critical internal factors in achieving internal environmental management efficacy. High levels of ecological dedication and support by top management on environmental issues are fundamental for green innovations [23]. Similarly, customer cooperation, an external environmental management efficiency element, plays a critical role in adopting green innovations [24].

Adopting and implementing green innovations are directly correlated with the managerial side because it helps businesses in creating green or sustainability competitive advantages [23]. Commitment by top management plays an essential role in transforming and developing a firm's managerial and organizational structures [13], thereby providing the necessary support to undertake and achieve green practices [12]. Correspondingly, closer coordination and cooperation with customers and other supply chain partners result in the successful adoption of green innovations $[25,26]$.

The conceptual model (see Figure 1) of this study connects top management commitment to customer cooperation and green innovations. Our research model first recognizes the role of top management commitment to building robust customer cooperation and adopting green innovations. Later, we examine how customer cooperation augments the adoption of green innovations in supply chains.

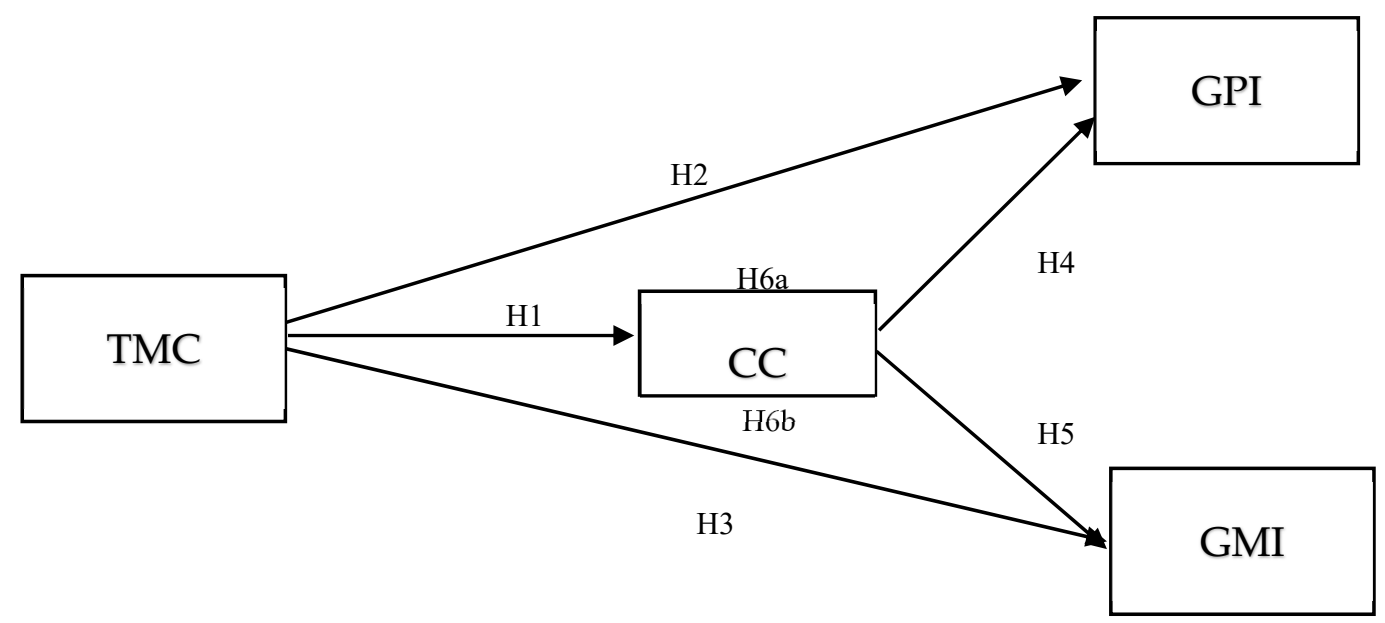

Figure 1. The Research Model.

\subsection{Top Management, Customer Cooperation and Green Innovations}

Concrete commitment towards sustainability by top management demonstrate that a firm will take necessary measures to develop and implement the required administrative and operational structures for implementing sustainability practices [12,27]. The absence of commitment to sustainability creates difficulties in adopting green practices and the sustainability vision in a firm [28]. Likewise, close cooperation with supply chain partners plays a critical role in adopting sustainable practices in 
supply chains [26]. When business firms provide sustainable solutions to their customers, it provides them with a competitive advantage in the market [22,29].

In a supply chain context, top management commitment to sustainability exhibits a supply chain's ability to minimize carbon footprint and deliver value to its customers. Increasing environmental awareness and preference for green products by consumers further heightened the need for close customer collaboration in supply chains. When supply chain partners collaborate on sustainability issues, it facilitates them in the adoption of green innovations and practices [30]. Commitment by top management strengthens customer cooperation because it helps them in achieving sustainable objectives [13]. Hence, we propose:

Hypothesis H1. There is a positive association between top management commitment to sustainability and customer cooperation.

A firm's top management plays a crucial role in implementing and managing sustainability issues [31]. Similarly, an active partaking by top managers is critical in adapting and achieving green process innovation [32]. Current research shows that outstanding commitment by senior managers to adjust and improve green process innovation improve environmental sustainability goals [18]. This feature provides top managers in improving green competitive advantages and underlining which factors differentiate their businesses from competitors [33]. Recent research [6] shows top management commitment to green process innovation has a positive effect on supply chains performance. Hence, we propose:

Hypothesis H2. There is a positive association between sustainable commitment by top management and green process innovation.

For improving environmental performance, top management actively monitors wide-ranging ecological policy matters and then act accordingly to modify the firm's internal commitments towards green innovations. Green managerial innovation is critical for developing internal environmental management efficiency and involves changing a firm's organizational and management structures. When top management supports green managerial innovations, it develops an internal environment that is more conducive to innovative solutions that enhance the green image of a firm [22]. Supporting green administrative changes helps in reducing the negative impact of supply chain operations on the environment. By following green managerial approaches, managers achieve commercial and green performance objectives in a supply chain $[17,22]$. Hence, we propose,

Hypothesis H3. There is a positive association between sustainable commitment by top management and green managerial innovation.

\subsection{Customer Cooperation and Green Innovations}

In supply chains, customer cooperation is a vital element for process innovation [34]. Close customer cooperation allows businesses to improve their process innovations capabilities in key supply chain areas such as product quality, lead-time and product development [35]. Close collaboration with customers also improves market share and builds competitive advantage [36,37]. Strategically, better customer cooperation provides necessary information about new market trends and emerging market demands. Consequently, innovation processes facilitate the development of new products. For instance, when customers demand temporary solutions to their difficulties, it expedites process innovation [38]. Other studies $[39,40]$ demonstrate that close customer cooperation improves process innovation. Hence, we propose,

Hypothesis H4. There is a positive association between customer cooperation and green process innovation. 
Reference [41] recognizes the role of customer cooperation in motivating partners to adopt and implement innovations. For instance, business firms develop active collaboration with their customers to create and enforce managerial innovations that maximize customer value [42]. In supply chains, close integration between manufacturers and customers has a positive effect on the firm's organizational innovation levels [43]. We propose,

Hypothesis H5. There is a positive association between customer cooperation and green managerial innovation.

\subsection{Mediation Effect}

Currently, industrial customers focus on developing innovative solutions to minimize their carbon footprints. Similarly, end-consumers have become more environmentally conscious. Therefore, end-consumers are interested in understanding the ways consumer products are manufactured and disposed of via global supply chains. When consumers become sensitive to environmental issues, it becomes vital for businesses to adopt green practices to maintain their competitive advantage [44]. Empirical evidence [12] underscores the role of customers in fostering and implementing green innovations. As the demand for green products grows, supply chains face rigorous scrutiny about raw material resources, manufacturing processes, and other supply chain related issues. Hence, it is crucial for green supply chain partners to show mutual commitment towards green practices.

Reference [45] show the manufacturer-customers partnership has a vital role in adopting green innovations and achieving overall environmental performance. Studies $[27,46,47]$ support the positive effect of other stakeholder commitment on achieving better environmental management outcomes. Better cooperation between supply chain partners on ecological issues positively affects green managerial innovations [48].

When business firms improve their relationships with customers, it strengthens green process innovation [48,49]. Integrating customers in achieving sustainability performance is vital because it provides supply chain the necessary flexibility to cater to the changing needs of customers. Cooperation with customers will improve process innovations [50] and resultantly, could reduce production waste and improve resource efficiency [51]. When environmental concerns become vital for customers, green practices such as green process innovations improve ecological performance [52].

In successful green supply chains, it is essential for business firms to develop and nurture a relationship with their customers. Achieving environmental sustainability implies business firms to simultaneously adopt and implement internal and external green innovation practices. In other words, reviving overall business operations towards better ecological management. Close customer cooperation should increase the successful adoption of green innovations. Hence, we propose:

Hypothesis H6a. Customer cooperation mediates the relationship between sustainable commitment by top management and green process innovation.

Hypothesis H6b. Customer cooperation mediates the relationship between sustainable commitment by top management and green managerial innovation.

\section{Empirical Setting and Measurements}

To test our research model empirically, we selected ISO 14000 certified Turkish exporting firms, located in the Izmir region (Turkey). We chose all the ISO 14000 exporting firms from the Izmir region. Two hundred and fifty (250) firms agreed to participate in the survey. The unit of analysis is the relationship between the Turkish manufacturing exporters and their most important customers placed in the European continent countries. The selected firms exported textile, chemical, food, electrical, 
electronics, manufacturing, and medical products. These firms have effectively adopted sustainable practices to attain environmental sustainability during their various manufacturing processes.

We applied the key informant approach [53] to collect primary data. All the respondents were working as business directors, export managers, and operations managers for more than five years in the respondent firms. They had complete knowledge about green innovations or green practices that manufacturing firms have adopted and implemented for their customers. Senior-middle managers and operational managers participated in the research. The respondents completed the survey by providing information about one strategic customer in mind. This attribute gives a better managerial perspective across a range of business firms. Out of 250 export-manufacturing firms, 181 firms completed the research survey. Lack of interest, time deficiency and other factors were cited for not completing the research questionnaire. One hundred eighty-one useable responses gave an extraordinary response rate of $72 \%$.

To control the possibility of common method bias, we followed some vital procedures. The questionnaire asked the respondent to rank the items of the constructs comparatively and not regarding bad versus good. Next, we conducted Herman's one-factor test. No single factor accounted for the most of variance when we performed factor analysis on the items of dependent and independent variables. In our study, common method bias problem seems irrelevant.

\subsection{Measurements}

In this section, we provide details about the dependent, independent and control variables. Customer cooperation (CC) refers to the extent of collaboration with a supply chain partner who eagerly contributes towards green practices, procedures, packaging, and recycling in achieving sustainability objectives in green supply chains. We selected items from previous studies (e.g., [13,27]). Green process innovation (GPI) items refer to the innovations that a respondent firm performs to save energy and reduce pollution prevention processes; whereas green managerial innovation (GMI) items report about the managerial attitude a firm commences to protect the environment. We selected items from previous studies $[17,22]$. Top management commitment (TMC), which refers to the level of commitment provided by the respondent firms' top management in achieving sustainability objectives. We selected items from previous studies [12,34] to measure the commitment construct.

We introduced firm size and relationship duration as control variables in our research model. Firm size represents the number of permanent employees in manufacturing units. This variable captured the strategic position of a manufacturing firm regarding its relationship with a specific customer. We incorporated into our research model by taking a natural logarithm of the number of permanent employees. Relationship duration is the second control variable and identifies the number of years a manufacturer has worked with a particular customer. We integrated a natural logarithm of the number of years doing business together with important customers to account for this effect.

\subsection{Validation of Constructs}

First, we carried out an exploratory factor analysis (EFA) and removed items that showed low or insignificant loadings. Next, we carried confirmatory factor analysis (CFA) to measure the discriminate validity of our measurement model by using AMOS 24. The fit indices of the four-factor solution $\left(\chi^{2}=105.14, \mathrm{df}=59.00\right.$, p-value $\left.=0.005\right)$. The indexes $\chi^{2} / \mathrm{df}=1.782, \mathrm{GFI}=0.921, \mathrm{CFI}=0.966$, $\mathrm{IFI}=0.966$, TLI $=0.955$, and RMSEA $=0.066$ endorse an acceptable fit for our four-factor model. Table 1 illustrates the constructs' items. Table 2 shows the correlation matric and the average variance extracted (AVE-in bold numbers) values of individual constructs, given in bold numbers. 
Table 1. Individual constructs and validity measures.

\begin{tabular}{|c|c|}
\hline Constructs & $\begin{array}{c}\text { The Constructs' Items Measured on 7-Point Likert-Type Scales with Endpoints Indicating } \\
\text { Strongly Disagree and Strongly Agree }\end{array}$ \\
\hline $\begin{array}{l}\text { Customer Cooperation } \\
\text { CC: } 4 \text { items } \\
\alpha=0.82, \mathrm{CR}=0.83\end{array}$ & $\begin{array}{l}\text { Our firm cooperates closely work with ... } \\
\ldots \text { this customer for green packaging. } \\
\ldots \text { this customer to achieve green handling procedures. } \\
\ldots \text { this customer to evaluate green sustainable practices. } \\
\ldots \text { this customer to implement green sustainable practices. }\end{array}$ \\
\hline $\begin{array}{l}\text { Green Managerial Innovation } \\
\text { GMI: } 2 \text { items } \\
\alpha=0.67, \mathrm{CR}=0.72\end{array}$ & $\begin{array}{l}\text { Our firm has redesigned ....... } \\
\ldots \text { operation and production processes to meet internal environmental efficiency. } \\
\ldots \text { and improved products and services to meet new environmental criteria. }\end{array}$ \\
\hline $\begin{array}{l}\text { Size of the firm } \\
\text { Relationship duration }\end{array}$ & $\begin{array}{l}\text { Size: The number of employers in the respondent firm (natural logarithm). } \\
\text { Time: The number of years our firm is doing business with this customer (natural logarithm). }\end{array}$ \\
\hline
\end{tabular}

Table 2. Correlation matrix.

\begin{tabular}{ccccccc}
\hline & TMC & CC & PI & MI & Size & Time \\
\hline TMC & $1.00(\mathbf{0 . 8 8})$ & & & & & \\
CC & 0.367 & $1.00(\mathbf{0 . 5 5})$ & & & & \\
GPI & 0.492 & 0.560 & $1.00(\mathbf{0 . 9 3})$ & & & \\
GMI & 0.160 & 0.153 & 0.204 & $1.00(\mathbf{0 . 5 7})$ & & \\
Size & 0.267 & 0.317 & 0.321 & 0.230 & 1.000 & \\
Time & 0.261 & 0.136 & 0.211 & -0.029 & 0.305 & \\
Mean & 3.6119 & 2.7196 & 2.8803 & 3.7459 & 3.8855 & 1.000 \\
S.D. & 1.0499 & 0.9093 & 1.3374 & 1.0443 & 1.3807 & 181 \\
N & 181 & 181 & 181 & 181 & 181 & 180 \\
\hline
\end{tabular}

\section{Results}

\subsection{SEM Analysis}

To empirically test the hypothesized relationships between our constructs (H1-H5), we did a structural equation model (SEM) in AMOS 24. The SEM model's indices showed a satisfactory model fit $\left(\chi^{2} / \mathrm{df}=1.593, \mathrm{GFI}=0.920, \mathrm{CFI}=0.967, \mathrm{IFI}=0.967, \mathrm{TLI}=0.955\right.$, and RMSEA $\left.=0.057\right)$. Table 2 shows the correlation matric and the average variance extracted (AVE) values of individual constructs are in bold numbers.

As predicted, the results show that top management commitment has positive and significant relationships with customer cooperation $(\beta=0.240, p<0.000)$ and green process innovation $(\beta=0.256, \mathrm{p}<0.000)$, supporting hypotheses $\mathrm{H} 1$ and $\mathrm{H} 2$. Top management commitment has a moderate significant relationship with green managerial innovation $(\beta=0.142, p<0.099)$ and hence hypothesis H3 is partially supported. Regarding hypotheses H4 and H5, customer cooperation has a positive and significant relationship with green process innovation $(\beta=0.755, p<0.000)$ and an insignificant relationship with green managerial innovation $(\beta=0.087, p>0.494)$.

\subsection{The Mediation Analysis}

To measure the mediation effect as formulated in hypotheses H6a and H6b, we followed the recommended bootstrapping bias-corrected confidence interval procedure [54,55] in structural equation modeling (SEM). By using AMOS 24, we applied 2000 samples to obtain the confidence 
intervals. This procedure generated $95 \%$ confidence intervals and Table 3 describes the mediation effect results.

Table 3. The mediation analysis in AMOS: Using a bootstrapping procedure.

\begin{tabular}{cccc}
\hline Paths & Direct Effect & Total Effect & Indirect Effect \\
\hline TMC $=>$ CC $=>$ GPI & $0.263(p<0.001)$ & $0.359(p<0.001)$ & $0.138(p<0.05)$ \\
TMC $=>$ CC $=>$ GMI & $0.201(p>0.149)$ & $0.009(p<0.090)$ & $-0.035(p>0.658)$ \\
\hline
\end{tabular}

The mediating effect results show a significant indirect effect of top management commitment (TMC) on green process innovations (GPI) through customer cooperation (CC), supporting our predicted H6a $(\beta=0.138, p<0.05)$. An insignificant indirect effect of TMC on green managerial innovation (MI) via CC shows that our predicted H6b is empirically insignificant $(\beta=-0.035, p>0.05)$. Hence, customer cooperation mediates the relationship between TMC and GPI, while customer cooperation fails to mediate the relationship between TMC and GMI. Our mediation results show the direct effect of TMC on customer cooperation, and customer cooperation on process innovation is positive and significant.

\section{Discussions and Conclusions}

This study examines the mediating role of customer cooperation in adopting green innovations in supply chains. Further, the study outlines the significant role of top management commitment in developing closer cooperative relationships with supply chain customers. Accordingly, our empirical results demonstrate that when supply chain partners collaborate in a synergic and reliable manner, sustainability objectives become achievable. Overall, the findings of this study augment the notion of establishing and maintaining close cooperation with supply chain customers result in reducing the negative impact of global supply chain operation on the environment. Furthermore, such an outcome also diminishes carbon footprint of supply chains.

When supply chains adopt green innovations, they develop sustainable competitive advantages. Green innovations are the dynamic capabilities [56] that identify and differentiate green supply chains from ordinary supply chains. In our study, the mediating role of customer cooperation in supply chains strengthens the dynamic capability towards sustainable competitive advantages. Similarly, the commitment by top management toward green innovations demonstrates the will of a firm to accomplish a specific dynamic skill towards sustainability. When each a supply chain entity strives for a particular dynamic capability to augment green supply chain sustainable objectives, close integration between suppliers, consumers, and management commitment becomes vital [56]. This demonstrates that the roles of customer cooperation and green innovations are critical in developing sustainable competitive advantage in an exchange setting [57].

Close cooperation between supply chains partners is vital for adopting green. innovations. This study identifies and provides empirical support to the logical relationship between top management commitment and customer cooperation in achieving sustainability objectives. Supply chain partners need tighter integration with key supply chain customers for strengthening environmental collaboration. For instance, exchanging manufacturing and logistics operations information, providing training to second and third tier suppliers, and coordinated cooperation for new products and the adoption of green technologies will result in realizing green supply chains.

The study finds that top management commitment (TMC) positively affect green process and green managerial innovations. In comparison to green process innovation, the impact of TMC on green managerial innovation is positive but modestly significant. A modest positive effect of TMC on GMI is explainable by the internal environmental management focus on green managerial innovation, whereas the significant positive effect of TMC on GPI demonstrates that changing an ordinary supply chain into a green supply chain demands close alignment with external supply chain 
partners. This strategy is essential in strengthening the overall green competence of a supply chain in achieving ecological benefits.

Customer cooperation has a significant positive effect on green process innovation, and an insignificant impact on green managerial innovation. The results indicate that close customer cooperation could act as one of the driving components for supply chains to achieve sustainability objectives. Green process innovation has an external orientation in supply chains. It demands making supply chains holistically more environment-friendly by executing green innovations in key processes such as manufacturing, transportation, etc., that improves resource efficiency. Managerial innovations reflect an organization's assurance towards better internal environmental management system and our results show an insignificant effect of customer cooperation on green managerial innovation. Nevertheless, a green supply chain needs a credible internal environmental management system for executing a permanent external environmental collaboration. Collectively, our findings suggest that when supply chain partners move towards better environmental management, they improve environmental management at both internal and external environment levels.

The study applied customer cooperation as a mediating variable. Green process innovation outlines continuous processes with external supply chain partners to improve material efficiency, productivity, reduce costs and mitigating the negative impact on environment. Green managerial innovation shows how individual supply chain partners strategize and implement internal environment management structures. The results show a significant mediation effect on green process innovation and an insignificant effect on green managerial innovation. Strategically, green managerial innovation provides the internal flexibility required by a supply chain partner to innovate accordingly with external customer requirements, whereas green process innovation indicates the competence and commitment towards external partners in realizing green supply chain objectives.

It is substantial for supply chain managers to understand the role of green capabilities in the world's current business settings. Supply chain manager should priorities various environmental beliefs and values in promoting a firm's green credentials in developing business relationships with their primary supply chain customers. Top management should strengthen as well as motivate green managerial capabilities of their managers. This study describes the strategic relevance of close customer collaboration in green supply chains.

Like other studies, this study has some limitations. We collected data from the manufacturer side only. Collecting data about greener practices and innovations from the customer side would augment this study results. The findings of the study reflect the relevance to the export industries in Turkey. Future studies should survey multiple countries to expand the results of this study, especially those located in the developing and emerging economies. It would be interesting to integrate and measure green purchasing, green quality management, and other green supply chain measures in future studies to examine the mediating role of customer cooperation.

Overall, the study contributes to the study of green supply chains. Commitments by top management and customer cooperation are critical in adopting as well as executing green innovations. This study strengthens the notion that both internal and external sustainable commitments yield positive outcomes in mitigating environmental degradation.

Author Contributions: U.B. contributed to the development of theoretical model, data analysis, and preparation of the first draft of the manuscript. P.E. contributed to the theoretical model and the hypotheses development. U.N. contributed in data analysis section and paper editing.

Funding: This research has no research grant.

Conflicts of Interest: The authors declare no conflict of interest.

\section{References}

1. Elkington, J. Partnerships from cannibals with forks: The triple bottom line of 21st-century business. Environ. Qual. Manag. 1998, 8, 37-51. [CrossRef] 
2. Nanath, K.; Pillai, R.R. The influence of green is practices on competitive advantage: Mediation role of green innovation performance. Inf. Syst. Manag. 2017, 34, 3-19. [CrossRef]

3. Dangelico, R.M.; Pujari, D.; Pontrandolfo, P. Green product innovation in manufacturing firms: A sustainability-oriented dynamic capability perspective. Bus. Strategy Environ. 2017, 26, 490-506. [CrossRef]

4. Wu, W.; Liu, Y.; Chin, T.; Zhu, W. Will Green CSR Enhance Innovation? A Perspective of Public Visibility and Firm Transparency. Int. J. Environ. Res. Public Health 2018, 15, 268. [CrossRef] [PubMed]

5. Lam, J.S.L.; Van de Voorde, E. Green Port Strategy for Sustainable Growth and Development. In Transport Logistics for Sustainable Growth at a New Level, International Forum on Shipping. Ports and Airports. Available online: http:/ / www.icms.polyu.edu.hk/Proceedings/Proceedings\%20of\%20IFSPA\%202012.pdf (accessed on 15 February 2019).

6. Burki, U.; Ersoy, P.; Dahlstrom, R. Achieving triple bottom line performance in manufacturer-customer supply chains: Evidence from an emerging economy. J. Clean. Prod. 2018, 197, 1307-1316. [CrossRef]

7. Chen, Y.; Lai, S.; Wen, C. The influence of green innovation performance on corporate advantage in Taiwan. J. Bus. Ethics 2006, 67, 331-339. [CrossRef]

8. GEMI. New Paths to Business Value; GEMI: Washington, DC, USA, 2001.

9. Sancha, C.; Wong, C.W.; Thomsen, C.G. Buyer-supplier relationships on environmental issues: A contingency perspective. J. Clean. Prod. 2016, 112, 1849-1860. [CrossRef]

10. Zhu, Q.; Sarkis, J.; Geng, Y. Green supply chain management in China: Pressures, practices and performance. Int. J. Oper. Prod. Manag. 2005, 25, 449-468. [CrossRef]

11. Guoyou, Q.; Saixing, Z.; Chiming, T.; Haitao, Y.; Hailiang, Z. Stakeholders' influences on corporate green innovation strategy: A case study of manufacturing firms in China. Corp. Soc. Responsib. Environ. Manag. 2013, 20, 1-14. [CrossRef]

12. Hoejmose, S.; Brammer, S.; Millington, A. “Green” supply chain management: The role of trust and top management in B2B and B2C markets. Ind. Mark. Manag. 2012, 41, 609-620. [CrossRef]

13. Burki, U.; Dahlstrom, R. Mediating effects of green innovations on interfirm cooperation. Australas. Mark. J. 2017, 25, 149-156. [CrossRef]

14. Gerstberger, C.; Yaneva, D. Analysis of EU-27 Household Final Consumption Expenditure-Baltic Countries and Greece Still Suffering Most from the Economic and Financial Crisis; Eurostat Statistics in Focus: Brussels, Belgium, 2013.

15. Gunday, G.; Ulusoy, G.; Kilic, K.; Alpkan, L. Effects of innovation types on firm performance. Int. J. Prod. Econ. 2011, 133, 662-676. [CrossRef]

16. Govindan, K.; Diabat, A.; Shankar, K.M. Analyzing the drivers of green manufacturing with fuzzy approach. J. Clean. Prod. 2015, 96, 182-193. [CrossRef]

17. Chen, Y.S. The driver of green innovation and green image-green core competence. J. Bus. Ethics 2008, 81, 531-543. [CrossRef]

18. Tseng, M.L.; Wang, R.; Chiu, A.S.; Geng, Y.; Lin, Y.H. Improving performance of green innovation practices under uncertainty. J. Clean. Prod. 2013, 40,71-82. [CrossRef]

19. Govindan, K.; Muduli, K.; Devika, K.; Barve, A. Investigation of the influential strength of factors on adoption of green supply chain management practices: An Indian mining scenario. Resour. Conserv. Recycl. 2016, 107, 185-194. [CrossRef]

20. Bernauer, T.; Engel, S.; Kammerer, D.; Sejas Nogareda, J. Explaining green innovation: Ten years after Porter's win-win proposition: How to study the effects of regulation on corporate environmental innovation? Work. Pap. 2006, 17, 1-16. [CrossRef]

21. Solberg Hjorth, S.; Brem, A.M. How to Assess Market Readiness for an Innovative Solution: The Case of Heat Recovery Technologies for SMEs. Sustainability 2016, 8, 1152. [CrossRef]

22. Chiou, T.Y.; Chan, H.K.; Lettice, F.; Chung, S.H. The influence of greening the suppliers and green innovation on environmental performance and competitive advantage in Taiwan. Transp. Res. Part E Logist. Transp. Rev. 2011, 47, 822-836. [CrossRef]

23. Roy, M.; Khastagir, D. Exploring role of green management in enhancing organizational efficiency in petro-chemical industry in India. J. Clean. Prod. 2016, 121, 109-115. [CrossRef]

24. Dangelico, R.M. Green product innovation: Where we are and where we are going. Bus. Strategy Environ. 2015, 25, 560-576. [CrossRef] 
25. Pereira de Carvalho, A.; Barbieri, J.C. Innovation and sustainability in the supply chain of a cosmetics company: A case study. J. Technol. Manag. Innov. 2012, 7, 144-156. [CrossRef]

26. Lee, K.H.; Kim, J.W. Integrating suppliers into green product innovation development: An empirical case study in the semiconductor industry. Bus. Strategy Environ. 2011, 20, 527-538. [CrossRef]

27. Zhu, Q.; Sarkis, J.; Lai, K.H. Institutional-based antecedents and performance of internal and external green supply chain management practices. J. Purch. Supply Manag. 2013, 19, 108-117. [CrossRef]

28. Gupta, H.; Barua, M.K. Modelling cause and effect relationship among enablers of innovation in SMEs. Benchmark. Int. J. 2018, 25, 1597-1622. [CrossRef]

29. Huang, Y.C.; Ding, H.B.; Kao, M.R. Salient stakeholder voices: Family business and green innovation adoption. J. Manag. Organ. 2009, 15, 309-326. [CrossRef]

30. Zhu, Q.; Sarkis, J.; Lai, K.H. Confirmation of a measurement model for green supply chain management practices implementation. Int. J. Prod. Econ. 2008, 111, 261-273. [CrossRef]

31. Chan, R.Y.; He, H.; Chan, H.K.; Wang, W.Y. Environmental orientation and corporate performance: The mediation mechanism of green supply chain management and moderating effect of competitive intensity. Ind. Mark. Manag. 2012, 41, 621-630. [CrossRef]

32. Kearns, G.S.; Sabherwal, R. Strategic alignment between business and information technology: A knowledge-based view of behaviors, outcome, and consequences. J. Manag. Inf. Syst. 2006, 23, 129-162. [CrossRef]

33. Lee, K.H. Why and how to adopt green management into business organizations? The case study of Korean SMEs in manufacturing industry. Manag. Decis. 2009, 47, 1101-1121. [CrossRef]

34. Zhu, Q.; Sarkis, J. Relationships between operational practices and performance among early adopters of green supply chain management practices in Chinese manufacturing enterprises. J. Oper. Manag. 2004, 22, 265-289. [CrossRef]

35. Chung, S.A.; Kim, G.M. Performance effects of partnership between manufacturers and suppliers for new product development: The supplier's standpoint. Res. Policy 2003, 32, 587-603. [CrossRef]

36. Arvanitis, S.; Lokshin, B.; Mohnen, P.; Wörter, M. Impact of external knowledge acquisition strategies on innovation: A comparative study based on Dutch and Swiss panel data. Rev. Ind. Organ. 2015, 46, 359-382. [CrossRef]

37. Mahr, D.; Lievens, A.; Blazevic, V. The value of customer cocreated knowledge during the innovation process. J. Prod. Innov. Manag. 2013, 31, 599-615. [CrossRef]

38. Gruner, K.E.; Homburg, C. Does customer interaction enhance new product success? J. Bus. Res. 2000, 49, 1-14. [CrossRef]

39. Belderbos, R.; Carree, M.; Lokshin, B.; Sastre, J.F. Inter-temporal patterns of R\&D collaboration and innovative performance. J. Technol. Transf. 2015, 40, 123-137. [CrossRef]

40. Chuang, S.H.; Lin, H.N. Co-creating e-service innovations: Theory, practice, and impact on firm performance. Int. J. Inf. Manag. 2015, 35, 277-291. [CrossRef]

41. Cui, A.S.; Wu, F. Utilizing customer knowledge in innovation: Antecedents and impact of customer involvement on new product performance. J. Acad. Mark. Sci. 2016, 44, 516-538. [CrossRef]

42. Homburg, C.; Droll, M.; Totzek, D. Customer prioritization: Does it pay off, and how should it be implemented? J. Mark. 2008, 72, 110-130. [CrossRef]

43. Koufteros, X.A.; Cheng, T.E.; Lai, K.H. "Black-box" and "gray-box" supplier integration in product development: Antecedents, consequences and the moderating role of firm size. J. Oper. Manag. 2007, 25, 847-870. [CrossRef]

44. Chen, Y.; Wang, Y.; Nevo, S.; Jin, J.; Wang, L.; Chow, W.S. IT capability and organizational performance: The roles of business process agility and environmental factors. Eur. J. Inf. Syst. 2014, 23, 326-342. [CrossRef]

45. Geffen, C.; Rothenberg, S. Sustainable development across firm boundaries: The critical role of suppliers in environmental innovation. Int. J. Oper. Prod. Manag. 2000, 20, 166-186. [CrossRef]

46. Wong, C.W.; Lai, K.H.; Cheng, T.C.E. Complementarities and alignment of information systems management and supply chain management. Int. J. Shipp. Transp. Logist. 2009, 1, 156-171. [CrossRef]

47. Da Silveira, G.J.; Arkader, R. The direct and mediated relationships between supply chain coordination investments and delivery performance. Int. J. Oper. Prod. Manag. 2007, 27, 140-158. [CrossRef] 
48. Zhu, Q.; Qu, Y.; Geng, Y.; Fujita, T. A comparison of regulatory awareness and green supply chain management practices among Chinese and Japanese manufacturers. Bus. Strategy Environ. 2017, 26, 18-30. [CrossRef]

49. Kim, Y.H.; Wemmerlöv, U. Does a supplier's operational competence translate into financial performance? An empirical analysis of supplier-customer relationships. Decis. Sci. 2015, 46, 101-134. [CrossRef]

50. Wallenburg, C.M.; Schäffler, T. The interplay of relational governance and formal control in horizontal alliances: A social contract perspective. J. Supply Chain Manag. 2014, 50, 41-58. [CrossRef]

51. Chang, C.H. The influence of corporate environmental ethics on competitive advantage: The mediation role of green innovation. J. Bus. Ethics 2011, 104, 361-370. [CrossRef]

52. Johansson, G.; Sundin, E. Lean and green product development: Two sides of the same coin? J. Clean. Prod. 2014, 85, 104-121. [CrossRef]

53. Heide, J.B.; John, G. Do norms matter in marketing relationships? J. Mark. 1992, 32-44. [CrossRef]

54. Preacher, K.J.; Hayes, A.F. Asymptotic and resampling strategies for assessing and comparing indirect effects in multiple mediator models. Behav. Res. Methods 2008, 40, 879-891. [CrossRef] [PubMed]

55. Strizhakova, Y.; Coulter, R.A.; Price, L.L. Branding in a global marketplace: The mediating effects of quality and self-identity brand signals. Int. J. Res. Mark. 2011, 28, 342-351. [CrossRef]

56. Pacheco, L.; Liboni, L. Dynamic capabilities for green innovations: A systematic literature review and propositions for future studies. In Proceedings of the EnANPAD 2017, São Paulo, Spain, 1-4 October 2017; pp. 1-16.

57. Ge, B.; Yang, Y.; Jiang, D.; Gao, Y.; Du, X.; Zhou, T. An empirical study on green innovation strategy and sustainable competitive advantages: Path and boundary. Sustainability 2018, 10, 3631. [CrossRef]

(C) 2019 by the authors. Licensee MDPI, Basel, Switzerland. This article is an open access article distributed under the terms and conditions of the Creative Commons Attribution (CC BY) license (http:/ / creativecommons.org/licenses/by/4.0/). 